\title{
FEATURES OF INFLUENCE OF MACROECONOMIC MEASURES OF TRANSFORMATION ON THE STATE DEBT POLICY
}

\author{
Roman RUDYK ${ }^{1}$, \\ Taras Shevchenko National University of Kyiv, Ukraine
}

\begin{abstract}
The objective is to study the relationship between the debt policy and vector of macroeconomic measures which is reflected in the transformation of structure of budget deficiency payments. Also, the article defines and characterizes three main phases of the government debt policy: pre-stabilization, stabilization and post-stabilization. The author analyzes main aspects of the relationship between dept policy and monetary one. Methodology. The study is based on the works of domestic and foreign scientists engaged in research of the given problem. Theoretical concepts are supported by statistical data of key macroeconomic indicators of Ukraine's economy. Results of the survey showed that the relationship between the debt policy and measures of macro-regulation during the transformation has the stable and permanent nature, and the use of certain instruments of government debt management is exclusively possible for a definite direction of macro policy on the one hand, and they are the elements in the system of measures for its implementation on the other hand. In the pre-stabilization phase of transformation the debt policy synthesizes the expansive solutions of monetary and fiscal authorities, and a direct link between them mediate the expansion of demand in the public sector and the preservation of soft budget constraints for micro-units; in the stabilization phase the relationship between fiscal, monetary and debt policy becomes more indirect, but are direct in that part of the borrowing purposes, subordinated to the creation of macro-stabilization mechanism of transformation; in the poststabilization period the role of indirect interconnection between the debt measures and fiscal and monetary decisions increases, but the lack of a deep micro-restructuring and deep systemic and structural reforms cause the deterioration in the macro-economic state of the system, due to which the vector of government borrowing again gravitates toward the field of formation of the mechanism of stabilization. In the post-stabilization period the following contradictions are especially intensely manifested: firstly, the contradictions between the expansive fiscal policy and relatively restrained monetary policy, which is why the maintenance of the exchange rate and inflation on the equilibrium level takes place with the higher interest rates; secondly, there is an enhancement of contradictions within the system of fiscal policy and monetary policy. The formation of consumer-oriented reproduction proportions of GDP is one of the consequences of such a situation.
\end{abstract}

Key words: debt policy, macroeconomic stabilization, monetary policy, investment policy, periods of debt policy, public debt management.

JEL Classification: H68, H63, G32

\section{Introduction}

The policy of government debt management is an important component of the ongoing financial policy and an essential component of the process of macroeconomic regulation. In a transformational economy the government debt management is the general expression of the state's attitude to financial resources.

As an important component of macroeconomic balancing the state borrowings have created a specific environment in which the impact on the dynamics of macroeconomic variables increasingly determined by measures of debt policy, rather than by the process of approaching the economy to equilibrium position (both by self-regulation and by indirect government intervention).

Considering the rapid accumulation of public debt in case of market transformation in Ukraine (and in other transformational economies) there is a steady dynamics of growth and increase of debt burdens in accordance with international standards of the country's burdensomeness estimation, and macroeconomic position of government debt is considered to be relatively unstable. Within this framework, debt is a determining factor in the process of structuring of budget expenditures and neutralization of Ukraine's balance of payments which determines the relevance of this study.

Corresponding author

${ }^{1}$ Department of Finance, Taras Shevchenko National University of Kyiv.

E-mail: rria@ukr.net 
The importance of place and role of the government debt in the financial system determined the constant attention of researchers to its various aspects. Special attention is given to the works of the following western researches: R. Barro, J. Buchanan, P. Elvort, N. Kaldor, J. Keynes, P. Krugman, A. Lerner, Karl Marx, R. Musgrave, L. Mauer, F. Mahlup, F. Modigliani, L. Pazynetti, David Ricardo, Adam Smith, John. Stiglitz, P. Harrod and others. Various aspects of analysis of this issue are disclosed in the works of Ukrainian scientists-financiers in particular in the writings of O. Baranovskyi, O. Vasylyk, T. Vakhnenko, V. Geyets, V. Koziuk, G. Kucher, V. Lisovenko, Z. Lutsyshyna, I. Liutyi, V. Novitskyi, L. Novosad, A. Plotnikov, V. Fedosov etc. External debts as an integral part of the modern international financial system were studied by such Russian scientists-economists as A. Vavilov, A. Sarkisyants, A. Fedyakina, etc.

The purpose of the article is to identify and describe features of influence of macroeconomic measures of transformation on the state debt policy.

\section{The features of macroeconomic measures in the transformational economy}

Macroeconomic measures in the transformational economy have a number of distinctive features that demonstrate special aspects of both transition to a market economy, and development of a qualitatively new model of state interference with the economy. This is related to the fact that:

- The transition to the macroeconomic regulation is carried out in a systematic and institutional vacuum which is filled gradually with the development of transformation. - Reformation of different sectors and spheres of the economy carried out at different rates which is occurs due to:

a) objective factors (various components of the economic system go trough the reforming with different intensity due to their functional, reproductive and technological features);

b) subjective factors (to some extent, the transformation process has selective character, which is connected with both ethical factor of market transformation and the social doctrine of transformation);

- macroeconomic measures mainly have features in the pre-stabilization phase of transformation (expansive policy) and in the stabilization and post-stabilization phases (restrictive and moderately simulative policy);

- the use of instruments of macroeconomic regulation by the government institutions is slightly faster than the development of the system of transmission of political and economic decisions to the sphere of reproduction as the final object of regulation;

- the formation of transmission channels for macrodecisions occurs with different intensity throughout the transformation. Depending on the features of industryreproductive structure and nature of market transformation the efficiency of macro-regulatory instruments, including leverages of deficit financing, will be differentiated in proportion to the development of the abovementioned system of impulse transmission.

The components of macro policies - fiscal, monetary and investment policies, which are divided by functional features - are systematically combined and implemented in interconnectedness with debt policy (which in principle is the part of fiscal policy). The content of the relationship between the debt policy and other types of macro policies can be manifested in such qualitative forms as: direct connection, when certain decisions regarding government debt can be directly attributed to a particular instrument of macro policies; indirect connection, when macrodecisions that lead or do not lead to changes in qualitative and quantitative parameters of the government debt are implemented through the use of debt instruments. The form of the relationship is changing during the process of market transformation. The relationship between debt and overall macroeconomic policies are sustainable and stable, and it is such that leads to the existence of the action field of mutual determination in which the tension increases in the process of macro-economic destabilization and decreases when the macro-system is in the relatively balanced state.

\section{The main phase of the debt policy of Ukraine}

The general vector of macroeconomic policies in the process of market transformation, in general, can be divided by stages of transformation (the first stage - liberalization, the second one - macro-stabilization and the third one system adjustments), consequently, there will be a close connection between the content of macro-decisions and the direction of implementation of debt policy (Sachs, J., Pivovarsky, A., 1996). Thus, in Ukraine the maintenance of constant structural deficit and preservation of the system of soft budget constraints in the pre-stabilization period against the background of rising prices is seen as an attempt to hold expansionary macroeconomic policies. Intensive deficit financing aimed at supporting the demand in the public sector and at the government acceptance of debt obligations of the subject of economic affairs in order to support demand in the state industrial sector reflect an attempt to prevent the transformational recession without going outside the framework of existing model of system organization of reproduction and avoiding the deep liberalization of economic activity. In such circumstances when the transmission channels for macro-regulation impulses have not built up yet, and the micro level, being in a state of adaptation to the market environment, is not able to respond with the supply elasticity to the strong signals of the demand, as well as the implementation of demand potential occurs according to the irrational system of budget expenditures organization and allocation of resources, monetization of the budget deficit, being reflected on the price growth, virtually left the sphere of supply inert to the integration of recovery incentives. Growing demand in the public sector within the framework of active fiscal and monetary measures 
that united in the system of deficit financing allowed supporting irrational economic decisions by shifting the inflatory-taxation burden to the society.

Processes of debt formation, which are subordinated to macroeconomic policy, combined fiscal and monetary measures. This is due to the fact that the expansion of domestic assets of NBU compensates for the deficit of tax revenues (emission for deficiency payments) and due to the fact that other measures were funded with emission which was written-off for government debt. As a result, trying to revive the situation in the real sector the government pursued expansionary fiscal and monetary policy, which is why the inflation explosion strengthened the tendency to unbalance the budget (The Olivera-Tanzi effect), therefore, the deficit financing switched to the self reproductive basis.

Given the above, in the initial phase of transformation the debt policy was in direct connection with fiscal and monetary ones and became almost the main instrument by means of which the priority measures of macro-regulation were materialized.

The necessity of taking macroeconomic policy off into the mode of stabilization led to the revision of the role of debt policy in the system of government regulatory measures.

However, this process has its own characteristics:

- in the stabilization period there was an attempt to limit the budget deficiency substantively for the anti-inflationary purpose. However, the fiscal policy in this period can not be considered restrictive;

- monetary control levers were subordinated to the objectives of deficit financing in the sense in which the fiscal imbalance and structure of deficiency payments serve as the imperative of the money supply of the central bank which, at the same time, conducted a pronounced restrictive policy using the available monetary policy tools; - taking into account experience of implementation of similar programs with the Bretton Woods institutions, in general, instrument of macroeconomic stabilization is not so much based on decisions regarding government debt as subordinated debt policy to the objectives of stabilization which eventually determines tendencies in the area of government debt;

- implementation of the stabilization policy has fundamentally updated the system of the relationship between fiscal and monetary policy on the one hand and the debt policy on the other. This is connected with the fact that some debt formation factors (including the formation of the stabilization monetary fund and balance of payments support) are directly subordinated to the task of stabilization, and others, which are connected with the development of debt instruments in the market direction, revealed themselves as indirect means of carrying out macroeconomic policy. Namely this gives place to the fact that starting from the stage of stabilization in the process of transformation the debt policy measures, with the development of marketoriented processes, retain their direct relationship with macroeconomic decisions, and created the preconditions for materialization of indirect connection with macroeconomic policy.

In the world practice there are well-known macroeconomic stabilization programs in which the exchange rate (Poland, Estonia, and Bulgaria) or money supply (Ukraine, Russia, Latvia, and Romania) used as the basis (Bofinger, P., Flassbeck G., \& Hoffmann, L., 1995). One can assume that in the system of macroeconomic stabilization, in which the exchange rate is seen by the monetary authorities as the basis, it is a necessity to have significant international reserves to prevent speculation in order to maintain its target value.

In Ukraine the money supply was chosen as the basis in the process of implementation of the macro-stabilization program but NBU started to form significant assets and liabilities in foreign currency namely with the help of credit cooperation with INF. Recent data on the structure of the PPG debt in view of repayment currency as at 31.12.2014 is shown in Figure 1.

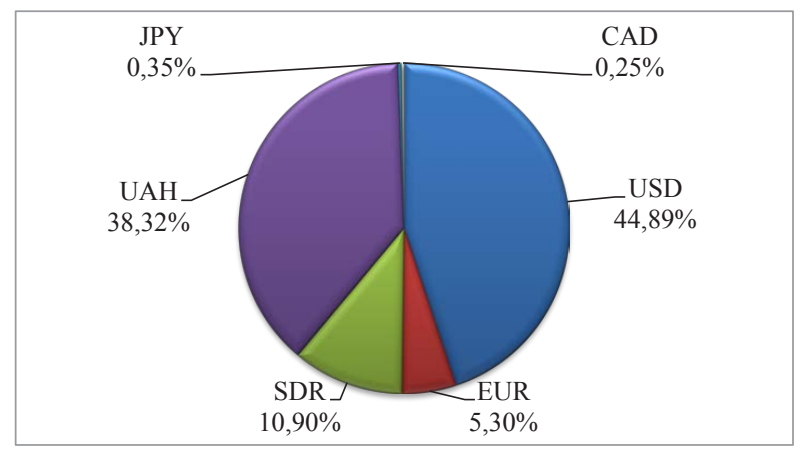

Fig. 1. Structure of public and publicly guaranteed debt by currency of repayment as of 31.12.2014 p.

Indirect connection of the debt policy with the measures for macroeconomic stabilization was materialized in transformation of the structure of the budget deficiency payment. As a result, the creation and emission of market debt instruments envisaged the replacement of NBU emission loans and the formation of domestic debt on a new basis.

Implementation of macro stabilization, being reflected on the deepening of reforms at the micro level, have an impact on the slowdown of free energy consumption by public sector enterprises through the accumulation of external debt.

If in the initial period of stabilization of the economy the dominance of direct connection of debt policy with macroeconomic measures was traced, then in the prestabilization period instruments of government loans are increasingly beginning to be used indirectly in the regulation of macroeconomic processes under the simultaneous preservation of dominant role of the state borrowing for the maintaining of fiscal policy.

Speaking from the perspective of the implementation of the stabilization doctrine transformation, the fiscal policy would have to have the nature restraining aggregate demand. At the same time, fiscal government decisions in 
the post-stabilization phase of reforms faced the effect of such transition regularity as repeated destabilization of the financial system (described by M. Dąbrowski), which determined the dominant role of deficit financing in such a policy.

Attempts to increase the aggregate demand in the transitional economy using the deficit financing without resorting to fiscal restriction in post-stabilization period are exposed to structural and institutional barriers. A. Siedenberg and L. Hoffmann note: “... as Kornai noted ... Keynesian effects will be actualized only after final formation of a strict budgetary environment: but as long as "socialistic" tendency of government expenditures towards the less productive sectors continues, this effect will be negative" (Siedenberg A., \& Hoffmann, L., 1998). Conduction of the soft fiscal policy, which is based on the debt expansion, will enhance the disbalance of reproduction processes without regard to systemic measures which would have positive macroand microeconomic consequences. As a result, channels of impulses transmission, from the point of view of decisions taken within a stimulating fiscal policy, not only do not undergo formation, but, on the contrary, experience growing tendency of their disintegration. The manifestation of crowding-out effect, reinforced by relatively tough monetary policy, appears on the separation of the real sector from monetary and budget ones.

The debt crisis in Ukraine, the gradual reduction in the primary deficit and the need to ensure a primary budget surplus with the purpose of the suspension of public debt growth imposes objective limits on the expansiveness of the fiscal policy. Redistribution of taxes for the benefit of creditors and repayment of the government debt level the demand promotion even in the short term. As a result, the multiplier the effect of which is caused by government expenditure will decrease in quantitative terms. What is more, the need to limit the expansive fiscal policy decisions by actualization and the intensity of formation of the primary surplus will have the necessary character at a time when, in proportion to the deepening of transformation, the economy will hypothetically respond positively to the stimulating impulses from the extension and restructuring of public sector expenditures. The problem of the reorganization of budget expenditures is closely linked to the transformation of direct subsidies for economic agents into the indirect. As some studies show, budget constraints at the micro level become softer in the process of harder budget constraints formation at the macro level in the poststabilization period and in the absence of systemic changes (Siedenberg A., \& Hoffmann, L., 1998). In other words, restrictive fiscal measures at the macro level are losing their effectiveness because the demand in non-productive sectors of the economy is increasing. According to our reckoning the objective limit in adoption of such a policy is the potential of accumulation of the government debt, considering its depletion, and the need to ensure primary budget surplus and certain level of social transfers in the budget. In this sense, the restraint of inefficient demand in the public sector will be compensated by the growth of marginal utility during the consumption of public goods.

Monetary policy as the part of macroeconomic regulation is released from the direct connection with the debt policy to the extent of strengthening of the stabilization tendencies and reform deepening. The transition to the financing of the budget deficit at the cost of loans on the market, weakening the emission activity of the NBU, has qualitatively upgraded the relationship between growth of the money supply and inflation, which is fundamental for the monetary regulation of macro processes.

\section{The main aspects of the relationship between dept and monetary policy}

The development of the government securities market has qualitatively upgraded the instrumental apparatus of the monetary policy within the framework of the approaching of the debt policy to the market standards.

In respect of the aspect of the relationship between the debt and monetary policies one can distinguish the following trends:

- firstly, the National Bank have got the opportunity to reorganize the system of refinancing of commercial banks by means of introduction of repurchase agreements and lombard crediting in the practice of monetary regulation; - secondly, in the process of development of the secondary market for government debt the National Bank have got the opportunity to conduct the open market operations, indirectly influencing the dynamics of interest rates and money supply dynamics. According to some studies (Piotrowska, M., 1998), namely open market operations have a considerable impact on the behavior of banks in the system of regulatory measures of Central Banks in transitional economies of Central Europe.

- thirdly, the establishment of the government securities market has made it possible for NBU to control bank liquidity minimizing the excess reserves, due to this the access to the currency market was limited for the speculative capital, at the same time, the permission for banks to form the part of statutory reserves at the expense of assets placed in domestic government loan obligations has increased the attractiveness of the last, on the one hand, and has eased a burden on reservation for banks, on the other hand;

- fourthly, yield rates dynamics on the market of government debt has become a determining indicator of the state of the monetary sector, depriving the NBU discount rate of these properties, at which, however, it was oriented almost to the time of the debt policy changing regarding internal borrowing;

- fifthly, liberalization of access of non-residences to the trading on the primary and secondary market of domestic government loan obligations allowed the NBU to expand its international assets and to cover a substantial part of current account deficit of the balance of payments;

- sixthly, the formation of reserves through the borrowings of the Ministry of Finance enabled the 
monetary authorities in Ukraine to reduce dependence on the IMF stabilization credits, at least in the short term.

Despite the expansion of operational capabilities of monetary regulation using the transactions on the market of government borrowing, debt expansion has led not only to the contradictions between monetary and fiscal policies, but also to contradictions in the system of monetary management at the macroeconomic level. The abovementioned is the regularity for majority of countries with the transitional economy where there is a real revaluation against the backdrop of public sector deficits, accompanied by a softening of Monetary and Credit Policy (Popov, V., 1999). However, the intensity of the manifestation of the abovementioned contradictions is correlated with the intensity of government borrowings.

Firstly, despite the soft fiscal policy in the poststabilization period, which entailed the expansion of the monetary base of the central bank, the exchange rate policy has been mainly of a stabilization nature.

Secondly, usually in the transitional economy, and especially in countries where there was a stabilization, where the increase of the money supply was elected as a basis, central banks choose directly monetary base and the exchange rate as the choice of tactical objectives of monetary policy, and when targeting money supply as an intermediate target they take into account the dynamics of the monetary base and the level of the money multiplier.

Considering the fact that the investments in government securities are virtually risk-free, and their yield rates in the transitional economies are higher than the world one, namely the debt expansion of the government is a factor that triggers a speculative capital floating. Ukraine is not the only country that faced this, and the manifestation of this phenomenon occurs with the increasing integration of financial markets in the world transformational systems.

For example, in Ukraine the intensive supply of domestic government loan obligations on the market attracted capital of the non-residents by pushing the interest rates. This, in turn, increased the demand for hryvnia and made it impossible to conduct the policy of moderate nominal devaluation to support the external balance. In this context, even at the decline in market interest rates foreign capital was attracted by the stable exchange rate, which provides high yield of domestic government loan obligations in foreign currency. The NBU maintenance of a stable, essentially fixed, exchange rate during the introduction of hryvnia was informal and had propagandist meaning; at the announcement of the currency corridor with a slight downward angle the NBU has officially pledged to maintain the stability of the nominal exchange rate. Therefore, the inflow of capital into the market of domestic government loan obligations resulted in its excessive revaluation, and trying to ease that process the National Bank expanded the monetary base through the formation of foreign assets, which is illustrated very well in Fig. 2.
The NBU did not try to sterilize the expansion of external assets at the time of inflow of capital into the market of domestic government loan obligations.

The capital outflow from the market of domestic government loan obligations while maintaining both tactical and intermediate objectives of monetary policy in terms of exchange rate has automatically retransmitted on the necessity to transfer it into restriction mode.

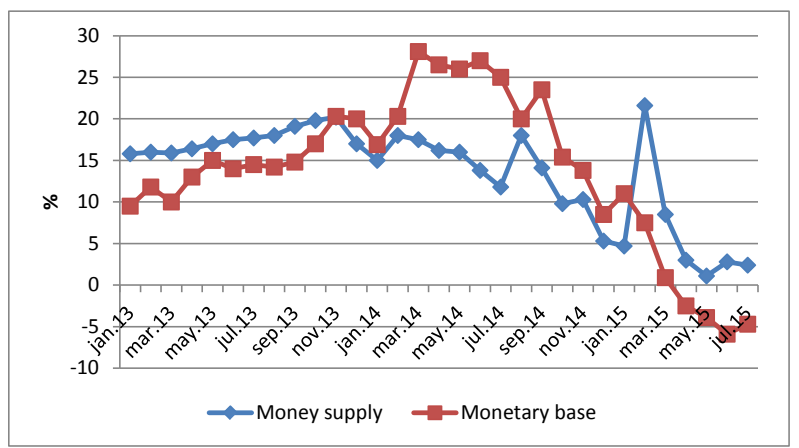

Report of the National Bank of Ukraine, 2015

Fig. 2. The growth of money supply and the monetary base in the years 2013-2015. (year on year change,\%)

However, the increasing interest rates and the yield on the government debt market could not resist the outflow of capital.

Formal analysis of the relationship of debt policy with reproductive one allows to state that it will have a direct character with the presence of adequate management model of allocation of the resources mobilized under the loan, in all other cases it will be indirect.

In this sense, the first case demonstrates the correlativity of the connection between the growth of public debt, as a consequence of the deficit, and the supply of public goods of consumer or capital nature. In Ukraine the growth of public debt does not mediate the growth of productive investment. The consumption of the public sector, concentrated using the tools of deficit financing, have only the current character since the capital expenditure is much smaller than the amount of the deficit.

The implementation of capital expenditure should not be based on the standards of industrial society, according to which, during the debt financing of needs of the state society is not impoverished only due to the increase of fixed assets of the economy), but on the basis of trends of the formation of post-industrial civilization. In accordance with the study of V. Andrushchenko (Andrushchenko, V., 1999) this requires updating the methodology for determining the investment costs by attributing to them the cost of R \& D and fundamental researches, investment in "human capital" and so on, the usefulness of which will be consumed by the present and future generations. Given the above, the implementation of the debt policy at the macro level should tightly determine the restructuring of micro-level, stimulating the role of the innovative aspects of development in the transformational process.

The government expenditures, being in systematic connection with the government borrowing, directly 
affecting a particular trend of consumption and accumulation depending on the structure of budget expenses and accommodation of resources mobilized under the debt. However, government expenditures stimulated by the government borrowings, in addition to its pronounced orientation on the current consumption, is a factor that, according to the study of I. Radionova, increasingly affects the state of external balance rather than the state of internal one (Radionova, J.F., 1999).

The maintenance of nominal exchange rate with the purpose of stabilization and anti-inflation theoretically acts as a factor stimulating the consumption. In addition to the fact that the exchange rate is an impact factor for the dominance of consumption in reproductive proportions it should be noted that it is an essential element in the system of communication of domestic productivity of factors and price level with the international ones. As it is shown in some studies (Melamed, M., 1998), at the beginning of the transformation in Ukraine the reaction to the low level of labor productivity, expressed in terms of GDP per capita, and to the prices, in comparison with the similar indicators in the USA, was naturally compensated by undervalued exchange rate.

\section{Conclusions}

The relationship between the debt policy and measures of macro-regulation during the transformation has the stable and permanent nature, and the use of certain instruments of government debt management is exclusively possible for a definite direction of macro policy on the one hand, and they are the elements in the system of measures for its implementation on the other hand. In the pre-stabilization phase of transformation the debt policy synthesizes the expansive solutions of monetary and fiscal authorities, and a direct link between them mediate the expansion of demand in the public sector and the preservation of soft budget constraints for micro-units; in the stabilization phase the relationship between fiscal, monetary and debt policy becomes more indirect, but are direct in that part of the borrowing purposes, subordinated to the creation of macro-stabilization mechanism of transformation; in the post-stabilization period the role of indirect interconnection between the debt measures and fiscal and monetary decisions increases, but the lack of a deep micro-restructuring and deep systemic and structural reforms cause the deterioration in the macro-economic state of the system, due to which the vector of government borrowing again gravitates toward the field of formation of the mechanism of stabilization. In the poststabilization period the following contradictions are especially intensely manifested: firstly, the contradictions between the expansive fiscal policy and relatively restrained monetary policy, which is why the maintenance of the exchange rate and inflation on the equilibrium level takes place with the higher interest rates; secondly, there is an enhancement of contradictions within the system of fiscal policy (restrictive tax policy and stimulating expenditure one) and monetary policy (in the process of intensive domestic borrowings and limited access to external markets the attempts to keep the money supply and the exchange rate at the target level is impossible and leads to the enhancement of credit restriction). The formation of consumer-oriented reproduction proportions of GDP is one of the consequences of such a situation.

\section{References}

Andrushchenko, V. (1999). Western Technology Investment diversification and intensification. Yalta- Foros, Ternopil: TANG: Proceedings of the Fourth International Conference "Problems of economic integration of Ukraine into the European Union: investment aspects", 66-70.

Bofinger, P., Flassbeck G., \& Hoffmann, L. (1995) Economics orthodox monetary stabilization: the example of Russia, Ukraine and Kazakhstan, Problems of Economics, (12), 26-44.

Siedenberg A., \& Hoffmann, L. (1998). Ukraine at a crossroads. Lessons from international experience of economic reforms, IL.: Phoenix.

Melamed, M. (1998). Structural relative prices and problems of economic growth in Ukraine: aspects of the analysis. Financial risks. Analytical Review, 2, 68-77.

Popov, V. (1999). Lessons currency crisis in Russia and other mills. Questions of economy, (6), 100-122.

Radionova, J.F. (1999) Macroeconomic fundamentals of roles between the Ministry of Finance and the National Bank. Finances of Ukraine, 2, 10-15.

Sachs, J., Pivovarsky, A. (1996). Economics of Transition. Lessons for Ukraine. Osnovy.

The National Bank of Ukraine (2015). Report of the National Bank of Ukraine. Retrieved July, 2015 from http:// www.bank.gov.ua/files/stat.pdf

Piotrowska, M. (1998). The Role of Polish Banks in Monetary Policy. Global Trends and Changes in East European Banking. Krakow.

\section{Роман РУДык}

\section{ОСОБЕННОСТИ ВЛИЯНИЯ МАКРОЭКОНОМИЧЕСКИХ МЕР ТРАНСФОРМАЦИИ НА ДОЛГОВУЮ ПОЛИТИКУ ГОСУДАРСТВА}

Аннотация. Целью работы является исследование взаимосвязи между заемной политикой и вектором макроэкономических мер, которая нашла свое отражение в трансформации структуры покрытия бюджет- 
Vol. 1, 2015

ного дефицита. Также, в статье определены и охарактеризованы три основные фазы долговой политики государства: достабилизационную, стабилизационную и постстабилизационную. Проведенный анализ основных аспектов взаимосвязи долговой политики с монетарной. Методология. Исследование основано на трудах отечественных и зарубежных ученых, занимающихся исследованием данной проблематики. Теоретические концепции подкрепляются статистическим данным основных макроэкономических показателей экономики Украины. Результаты исследования показали, что взаимосвязь между долговой политикой и мерами по макрорегулированию на протяжении трансформации имеет устойчивый и постоянный характер, а использование тех или иных инструментов управления государственным долгом с одной стороны возможно исключительно при определенном направлении макрополитики, с другой - они являются элементами в системе мероприятий по ее реализации. В достабилизационной фазе трансформации долговая политика синтезирует в себе экспансивные решения денежной и фискальной власти, а непосредственная связь между ними опосредует расширение спроса в государственном секторе и сохранения мягких бюджетных ограничений для микроединиц; в стабилизационной фазе взаимосвязь между фискальной и монетарной и долговой политикой приобретает все более непрямой характера, однако является непосредственным в той части целей заимствований, которые подчинены созданию макростабилизационного механизма трансформации; в постстабилизационном периоде роль косвенного взаимосвязи долговых мероприятий с фискальными и монетарными решениями усиливается, однако отсутствие глубокой микрореструктуризации и глубоких системноструктурных реформ обусловливают ухудшение макроэкономического состояния системы, из-за чего вектор государственных заимствований снова тяготеет к сфере формирования механизма стабилизации. В постстабилизационный период особенно остро проявляются противоречия: во-первых, между экспансивной фискальной и относительно сдержанной монетарной политикой, из-за чего поддержания валютного курса и инфляции на равновесном уровне имеет место при более высоких процентных ставках; во-вторых, усиливаются противоречия внутри системы фискальной политики (ограничительная налоговая политика и стимулирующее расходная) и монетарной (при интенсивных внутренних заимствований и ограниченного доступа к внешним рынкам попытки поддерживать на целевом уровне денежную массу и валютный курс оказывается невозможным и приводит к усилению рестрикции кредита). Одним из последствий такой ситуации является формирование потребительски-ориентированных воспроизводственных пропорций ВВП. 